\title{
Calcium and Potassium Imbalance Favours Leaf Blight and Defoliation Caused by Calonectria pteridis in Eucalyptus Plants
}

\author{
Thaissa P. F. Soares ${ }^{1}{ }^{(}$, Edson A. Pozza $^{1}$, Adélia A. A. Pozza ${ }^{2}{ }^{\circledR}$, Reginaldo Gonçalves Mafia ${ }^{3}$ \\ and Maria A. Ferreira $1, * \mathbb{D}$ \\ 1 Department of Plant Pathology/DFP, Universidade Federal de Lavras/UFLA, Lavras, MG 37200-000, Brazil; \\ thaissapfs@gmail.com (T.P.F.S.); edsonpozza@gmail.com (E.A.P.) \\ 2 Department of Plant Pathology/DCS, Universidade Federal de Lavras/UFLA, Lavras, MG 37200-000, Brazil; \\ adeliapozza@gmail.com \\ 3 Centro de Tecnologia, Fibria Celulose S.A., Rod. Aracruz Barra do Riacho, Km 25., Aracruz-ES 29197-900, \\ Brazil; rgoncalves@fibria.com.br \\ * Correspondence: mariaferreira@dfp.ufla.br; Tel.: +55-(35)-3829-1799
}

Received: 26 October 2018; Accepted: 13 December 2018; Published: 18 December 2018

\begin{abstract}
The supply of nutrients in balanced proportions leads to greater crop yields and represents an alternative practice for the management of plant diseases. Accordingly, we investigated the effect of the doses of and the nutritional balance between calcium (Ca) and potassium $(\mathrm{K})$ on the severity of leaf spot and defoliation caused by the fungus Calonectria pteridis. Moreover, the effect of the treatments on the growth of interspecific hybrid eucalyptus clone seedlings (Eucalyptus grandis Hill ex Maiden $\times$ E. urophylla S.T. Blake), which are highly susceptible to the disease, was evaluated. The 25 treatments comprised combinations of one of five doses of $\mathrm{Ca}\left(1.2,3.0,6.0,9.0\right.$ and $\left.12.0 \mathrm{mmol} \mathrm{L}^{-1}\right)$ with one of five doses of $\mathrm{K}\left(0.8,2.0,4.0,8.0\right.$ and $\left.12.0 \mathrm{mmol} \mathrm{L}^{-1}\right)$ and five replicates of each treatment were included in the study. The supply of high concentrations of $\mathrm{K}$ favoured $C$. pteridis infection and resulted in high disease severity, although defoliation was not observed. However, the supply of both nutrients in excess $\left(12.0 \mathrm{mmol} \mathrm{L}^{-1} \mathrm{Ca} \times 9.0 \mathrm{mmol} \mathrm{L}^{-1} \mathrm{~K}\right)$ resulted in a higher disease severity and an increased defoliation percentage ( 82 and $64 \%$, respectively). Defoliation not associated with Calonectria leaf blight disease was observed with the imbalanced treatments, that is, the treatments combining a low concentration of one nutrient and an excess concentration of the other nutrient. The supply of $\mathrm{K}$ at a level near the standard dose $\left(6 \mathrm{mmol} \mathrm{L}^{-1}\right)$ and of $\mathrm{Ca}$ at a dose above $4 \mathrm{mmol} \mathrm{L}^{-1}$ (standard dose) ensured high mean values for the morphological variables root and shoot biomass, plant height and chlorophyll a and $\mathrm{b}$ contents. These treatments also resulted in low disease severity and defoliation percentages, indicating that a balanced supply of $\mathrm{Ca}$ and $\mathrm{K}$ ensures reductions in disease severity and defoliation and contributes to higher growth.
\end{abstract}

Keywords: disease resistance; plant nutrition-disease relationship; eucalyptus disease; leaf spot; control

\section{Introduction}

Eucalyptus (Eucalyptus sp.) farming has grown rapidly to meet the growing world demand for pulp, paper and coal for the steel industry. In addition, the use of eucalyptus biomass and pulp as raw materials for the production of biofuels and biomaterials has been evaluated [1-3]. Brazil is the world's largest producer of eucalyptus, with a planted area of 5.67 million hectares [1]. More recently, eucalyptus plantations have undergone rapid expansion toward the northern and north-eastern regions of the country and the warm-temperature and high-humidity conditions of these regions are favourable for several diseases, particularly leaf blight caused by Calonectria species [4]. 
Calonectria species (anamorph: Cylindrocladium) are known to cause the disease Calonectria leaf blight (CLB) [5], which is mainly observed in eucalyptus trees and other diseases, including damping-off, cutting rot and root rot, have also been associated with Calonectria sp. [4]. The symptoms of CLB in most Eucalyptus species include spots that are initially small, circular or elongated and grey or light brown in colour and these spots progress and extend throughout the leaf limb to result in leaf drop and sometimes severe defoliation [6,7]. Defoliation caused by the pathogen is mainly observed in stages of plant development and interferes with physiological processes, such as photosynthesis, to induce a volumetric increase in the plant [8].

The leaf blight and severe defoliation caused by CLB in the northern and north-eastern regions of the country are mainly the result of infection with Calonectria pteridis Crous, M.J. Wingf. \& Alfenas and can occur during the seedling production phase in the field, particularly in forests aged up to three years. In nurseries, the environmental conditions implemented for the production of cuttings, which include high humidity frequent irrigation, favour the growth of this pathogen and the plant's spatial density also favours the development of CLB. The disease is currently controlled by integrated cultivation and chemical methods as well as by the selection and multiplication of resistant genotypes, which is a much more effective approach. These integrated practices reduce the initial inoculum and render the environmental conditions unfavourable to the pathogen [9]. In the field, the selection and use of resistant genetic materials is the only commonly used control method [4].

However, the planting of clones that are considered resistant in regions other than those where the selective breeding was performed constitutes a major problem. In many cases, high disease severity has been observed in clones that are considered resistant but are planted in regions with a distinct climate that favours fungal growth. Thus, the fact that the breeding programs do not consider a variety of regions and climatic factors has resulted in the inappropriate use of these clones.

Therefore, the integrated management of CLB through an adequate nutritional balance might represent an alternative method for the control of leaf blight disease in eucalyptus in both nurseries and the field. Plant nutrition is known to exert direct and indirect effects on the activation of defence mechanisms against infection by phytopathogens [10,11]. Mineral nutrients are critical for the formation of physical and / or chemical barriers involved in plant resistance. Thus, balanced fertilization represents an alternative control method but this approach requires knowledge of the interactions between nutrients and their influence on the intensity of a given disease. Such data are important because of the synergism and antagonism between mineral elements, which mainly occur due to competition for the same absorption sites [12,13].

The balance between calcium and potassium has been well studied from a nutritional perspective because these nutrients play a key role in plant defence, growth and metabolism [11,14]. Potassium is involved in enzyme activation, protein synthesis, stomatal opening and plant water flow and interacts at various levels in processes associated with hormone defence, such as in the jasmonic acid and ethylene pathways [15]. In turn, calcium influx through the plasma membrane signals plant defence responses, which demonstrates that calcium plays a fundamental role in pathogen recognition [16]; moreover, calcium participates in cell wall synthesis and might represent one of the more important nutrients that can potentially aid the management of plant diseases [17].

In eucalyptus, the influence of nutrients on the severity of leaf spot caused by CLB is unknown. In addition, there is scarce knowledge regarding the effects of an unbalanced supply of nutrients on both the resistance and the morphological characteristics of the plant. The balanced mineral fertilization constitutes a strategy to restrict the conditions that favour pathogen attack and symptom expression. Then, these strategies can be easily integrated into management programs for eucalyptus diseases. The objectives of this study were to investigate the effect of the calcium/potassium $(\mathrm{Ca} / \mathrm{K})$ ratio on the severity of leaf blight and the degree of defoliation caused by Calonectria pteridis and to evaluate the growth responses of eucalyptus under conditions of nutrient imbalance. 


\section{Materials and Methods}

\subsection{Plant Preparation and Implantation}

The experiment was conducted in a greenhouse with temperature and relative humidity conditions of $25 \pm 2{ }^{\circ} \mathrm{C}$ and $80 \%$, respectively, which were monitored by a datalogger HT-500 data logger (Instrutherm ${ }^{\circledR}$, São Paulo, SP, Brazil) located inside a meteorological shelter located $2 \mathrm{~m}$ from the experimental site. Seedlings of the hybrid clone of Eucalyptus grandis $\times$ E. urophylla, which are susceptible to C. pteridis, were removed from $53-\mathrm{cm}^{3}$ tubes at 50 days of age. The cultivation substrate was then removed under running water. The exposed roots were carefully washed and disinfested with $1 \%$ sodium hypochlorite for $1 \mathrm{~min}$ and the seedlings were transplanted to 6-L trays containing Clark's nutrient solution [18] modified with the respective treatments for acclimatization.

In the acclimation phase, the seedlings remained in trays with nutrient solution diluted to $25 \%$ ionic strength for 7 days. After new leaf pairs and/or secondary roots emerged, the solutions were replaced with $60 \%$ ionic strength solution. The seedlings remained under this condition for another 7 days.

After the adaptation phase, uniform seedlings within each treatment were transplanted into 3-L plastic pots containing Clark's nutrient solution with 100\% ionic strength according to the respective treatments and the seedlings were maintained under these conditions for another 25 days. The total experimental period from the acclimation phase to the end of the evaluations was 39 days.

The 25 treatments consisted of combinations of one of five doses of $\mathrm{K}(1.2,3.0,6.0,9.0$ and $\left.12.0 \mathrm{mmol} \mathrm{L}{ }^{-1}\right)$, which was provided as $\mathrm{KNO}_{3}$ and $\mathrm{KCl}_{2}$, with one of five doses of $\mathrm{Ca}(0.8,2.0,4.0$, 8.0 and $12.0 \mathrm{mmol} \mathrm{L}{ }^{-1}$ ), which was provided as $\mathrm{Ca}\left(\mathrm{NO}_{3}\right)_{2}$ and $\mathrm{CaCl}_{2}$, in a $5 \times 5$ factorial scheme. The experiment was performed based on a randomized block design with five replications and each experimental unit (pot) included two eucalyptus seedlings.

The micronutrient solutions were prepared with Fe-EDTA $\left(89.53 \mu \mathrm{mol} \mathrm{L}^{-1}\right)$, manganese sulphate $\left(91.01 \mu \mathrm{mol} \mathrm{L}^{-1}\right)$, zinc sulphate $\left(0.76 \mu \mathrm{mol} \mathrm{L}^{-1}\right)$, copper sulphate $\left(0.3153 \mu \mathrm{mol} \mathrm{L}{ }^{-1}\right)$, boric acid $\left(46.25 \mu \mathrm{mol} \mathrm{L}^{-1}\right)$ and ammonium molybdate $\left(0.10 \mu \mathrm{mol} \mathrm{L}{ }^{-1}\right)$. All the solutions were prepared using pure analysis-grade reagents. The concentrations of $\mathrm{K}$ and $\mathrm{Ca}$ used in the experiment were established based on the standard doses in Clark's solution [18] for these nutrients: thus, the five concentrations included the control doses of $6 \mathrm{mmol} \mathrm{L}^{-1} \mathrm{~K}$ and $4 \mathrm{mmol} \mathrm{L}^{-1} \mathrm{Ca}$ and two doses higher than and two doses lower the standard doses.

The roots were maintained under constant aeration in the nutrient solutions. The $\mathrm{pH}$ of the solutions was checked at three-day intervals with a digital $\mathrm{pH}$ meter (HANNA ${ }^{\circledR}$ Instruments, Ann Arbor, MI, USA) and corrected when necessary to 5.5-6.0 through the addition of $0.1 \mathrm{~mol} \mathrm{~L}^{-1}$ $\mathrm{KOH}$ or $\mathrm{HCl}$. The volume of the pots was refreshed as needed with deionized water. The electrical conductivity (EC) in each treatment was monitored weekly with a conductivity meter (HANNA ${ }^{\circledR}$ Instruments, Ann Arbor, MI, USA) at all stages to determine whether the solution needed to be replaced and the solution was not replaced if the decrease in EC did not reach $50 \%$ of the initial $\mathrm{K}^{+}$value.

The outside of the pots was painted with reflective silver paint to prevent the entrance of light and algal proliferation. In addition, the plant stems were attached to Styrofoam blocks in the upper face of the pots to prevent the entrance of light and support the seedlings.

\subsection{Inoculum Preparation and Inoculation}

Cultures of the C. pteridis isolate A2 were prepared in potato-dextrose-agar (PDA) medium. The fungus isolate was obtained from eucalyptus plantations in the state of Maranhão and maintained in the fungal collection of the Laboratory of Pathology, Federal University of Lavras (Universidade Federal de Lavras-UFLA). For inoculum production, the mycelium was cultured for 7 days for subsequent induction of sporulation by scraping the aerial mycelium and submersing the cultures in water [19]. The inoculum suspension was prepared by adding $20 \mathrm{~mL}$ of distilled water $+0.05 \%$ Tween 20 to the culture surface and then removing the conidia by scraping with a brush. The suspension was 
filtered through a double layer of sterilized gauze and the inoculum concentration was adjusted to $1.0 \times 10^{4}$ conidia $/ \mathrm{mL}^{-1}$ using a Neubauer chamber. The suspension was sprayed on all the leaves of the seedlings until runoff. The seedlings were then covered with dark plastic bags to ensure constant leaf wetting in this environment and deionized water was frequently sprayed to ensure maintenance of the humidity levels. The seedlings remained under these conditions, which were ideal for germination and pathogen penetration, for $48 \mathrm{~h}$.

\subsection{Experimental Evaluation}

\subsubsection{Disease and Defoliation Assessment}

Severity of CLB were evaluated when the first symptoms were observed in the leaves, that is, at $24,48,72,96$ and $120 \mathrm{~h}$ after inoculation (hai).

Disease severity was assessed by photographing the second fully expanded leaf pair at a distance of $10 \mathrm{~cm}$ after each evaluation period. The images were analysed using Quant ${ }^{\circledR}$ software [20] to obtain the percentage of the injured area as a function of the total leaf area.

The area under the disease progress curve (AUDPC) was calculated according to Shaner and Finney [21]:

$$
A U D P C=\sum_{i=l}^{n-1}\left(\frac{y_{i}+y_{i+l}}{2}\right)\left(t_{i+l}-t_{i}\right)
$$

where $y_{i}$ is the proportion of the disease at the i-th observation; $t_{i}$ is the time (in days) of the i-th observation; and $n$ is the total number of observations.

The severity values obtained at $120 \mathrm{~h}$ were analysed separately as the final severity (FS). The total number of leaves prior to inoculation and that remaining at the end of the evaluation period were counted to determine the defoliation percentage according to the following equation:

$$
F S(\%)=100-\frac{100 \times Q f}{Q i}
$$

where $D$ represents the percentage of defoliation, $Q i$ is the number of leaves prior to inoculation and Qf refers to the final quantity of leaves.

\subsubsection{Plant Growth and Chlorophyll Content}

Four morphological variables were evaluated: shoot height $(\mathrm{H})$, which was measured from the collar to the apical bud; collar diameter (CD), which was measured at the base of the collar; dry shoot weight (DSW); and dry root weight (DRW). At the end of the experiment, the roots were separated from the shoots and all the parts were washed in distilled water, packed in paper bags and dried in an oven at $60^{\circ} \mathrm{C}$ to a constant weight.

The Dickson quality index (DQI) [21] was obtained using the following formula:

$$
D Q I=\frac{T D W}{H / C D}
$$

where TDW (total dry weight) corresponds to the sum of DSW and DRW, $H$ represents the height and $C D$ is the collar diameter.

The chlorophyll content of the leaves was determined using a portable chlorophyll meter (PAD-502 ${ }^{\circledR}$, Minolta, Osaka, Japan) [22]. Four readings were performed on the second fully expanded leaf pair (two readings on each leaf) one day prior to inoculation and five days after inoculation. The mean of the four readings was used for the analysis. The chlorophyll $a$ and $b$ contents $\left(\mathrm{mg} \mathrm{gmf}^{-1}\right)$ were determined using the following equations in accordance to a previous study [23]:

$$
\text { hlorophyll } a=\frac{\left(12.7 \times A_{663}-2.69 \times A_{645}\right) \mathrm{V}}{1000 \mathrm{FMW}}
$$




$$
\text { Chlorophyll } b=\frac{\left(22.9 \times A_{645}-4.68 \times A_{663}\right) V}{1000 \mathrm{FMW}}
$$

where $A$ is the absorbance at the indicated wavelength, $V$ refers to the final volume of the chlorophyll-acetone extract and FMW represents the fresh weight in grams of plant material used $\left(\mathrm{mg}(\mathrm{g} \mathrm{MF})^{-1}\right)$.

The following equations were used to determine the chlorophyll $a$ and $b$ concentrations:

$$
\begin{gathered}
Y a=(0.008 \times X)-0.0053 \\
Y b=(0.0004 \times X)-0.0032
\end{gathered}
$$

where $X$ corresponds to the reading of the chlorophyll meter, Ya refers to chlorophyll $a$; and $Y b$ corresponds to chlorophyll $b$.

\subsection{Determination of the Leaf Nutrient Contents}

Leaves were collected prior of the implementation of the treatments and after the end of the experiment to determine the nutritional status of the cuttings. The $\mathrm{Ca}$ and $\mathrm{K}$ contents were determined according to the method described by Malavolta et al. [24]. The reference values used to interpret the results of the leaf analysis were based on the work conducted by Martinez et al. [25] for eucalyptus.

\subsection{Statistical Analysis}

The data were subjected to the Shapiro-Wilk [26] and Bartlett tests to evaluate the normality of the distribution of the residuals and the homogeneity of the variances, respectively. The data did not need to be transformed because the values met the assumptions of the analysis of variance. The means of the studied variables were compared using the $\mathrm{F}$ test $(p<0.05)$ and significant values were subjected to a regression analysis and fitted to the linear models that are most representative of the studied pathosystem. The significant interactions between the studied quantitative factors were plotted on response surface diagrams. The statistical analyses were performed using the statistical software $\mathrm{R}$ and graphs were produced using SigmaPlot v. 16.0 (SigmaPlot, SYSTAT Software, Inc., San Jose, CA, USA).

\section{Results}

\subsection{Disease Severity}

The first symptoms were observed at 48 hai and an interaction was observed between the $\mathrm{K}$ and Ca doses for the AUDPC $(p=0.0000)$, final severity $(p=0.0000)$ and defoliation $(p=0.0000)$. At all doses supplied, the disease showed progression over time and mean severity values greater than $30 \%$ were observed at the last evaluation (Figure 1).

The supply of $12 \mathrm{mmol} \mathrm{L}^{-1} \mathrm{~K}$ with all tested doses of Ca resulted in a high final severity (FS) (59 to $78 \%$ ) (Figure 2A). However, the highest FS (mean of $82 \%$ ) was obtained with $9 \mathrm{mmol} \mathrm{L}^{-1} \mathrm{~K}$ and $12 \mathrm{mmol} \mathrm{L}^{-1} \mathrm{Ca}$. A moderate severity response was observed with the standard doses of the nutrients $\left(6 \mathrm{mmol} \mathrm{L}^{-1} \mathrm{~K} \times 4 \mathrm{mmol} \mathrm{L}^{-1} \mathrm{Ca}\right)$ and with the treatments with low concentrations of $\mathrm{K}$. The interaction between $9 \mathrm{mmol} \mathrm{L}^{-1} \mathrm{~K}^{-1}$ and $8 \mathrm{mmol} \mathrm{L}^{-1}$ Ca yielded the lowest $\mathrm{FS}$ of $24.19 \%$.

The combinations of $3 \mathrm{mmol} \mathrm{L}^{-1} \mathrm{~K}$ with $9 \mathrm{mmol} \mathrm{L}^{-1} \mathrm{Ca}$ and of $4 \mathrm{mmol} \mathrm{L}^{-1} \mathrm{~K}$ with $8 \mathrm{mmol} \mathrm{L}^{-1} \mathrm{Ca}$ resulted in the lowest AUDPC values (1598.9 and 1955.8, respectively) (Figure 2B), whereas the supply of $9 \mathrm{mmol} \mathrm{L}^{-1} \mathrm{~K}$ and $12 \mathrm{mmol} \mathrm{L}^{-1}$ Ca yielded higher AUDPC values. The highest defoliation was also obtained with the treatments consisting of $9 \mathrm{mmol} \mathrm{L}^{-1} \mathrm{~K}$ with $12 \mathrm{mmol} \mathrm{L}^{-1} \mathrm{Ca}$ and $12 \mathrm{mmol} \mathrm{L}^{-1} \mathrm{~K}$ with $12 \mathrm{mmol} \mathrm{L}^{-1} \mathrm{Ca}$, which yielded defoliation percentages of $64 \%$ and $54 \%$, respectively (Figure $2 \mathrm{C}$ ). High defoliation percentages ranging from $39 \%$ to $63 \%$ were also observed after the treatments consisting of low doses of $\mathrm{K}$ and varying doses of $\mathrm{Ca}$ (except for values close to the standard dose). In addition, low doses of $\mathrm{Ca}$ combined with variable doses of $\mathrm{K}$ resulted in substantial defoliation $(30 \%-63 \%)$. The supply of $\mathrm{Ca}$ at a dose higher than the established standard dose $\left(4 \mathrm{mmol} \mathrm{L}^{-1}\right)$ 
combined with the standard dose of $\mathrm{K}\left(6 \mathrm{mmol} \mathrm{L}^{-1}\right)$ resulted in low defoliation and the interaction between $6 \mathrm{mmol} \mathrm{L}^{-1} \mathrm{~K}$ and $8 \mathrm{mmol} \mathrm{L}^{-1} \mathrm{Ca}$ yielded a low defoliation percentage of 3.9\% (Figure 2C).

A

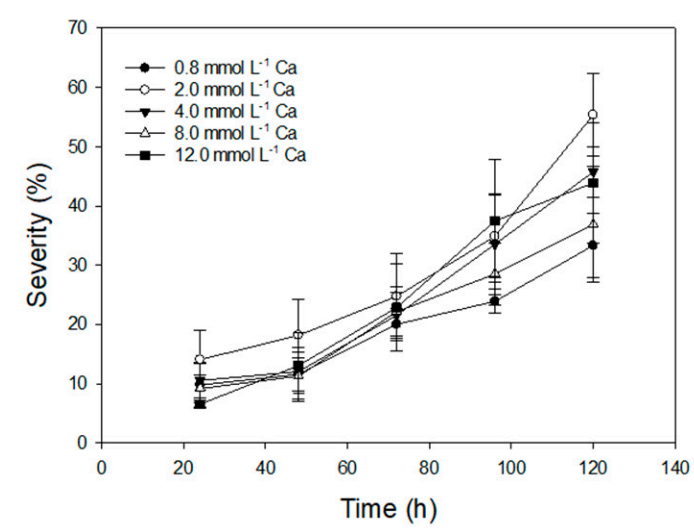

C

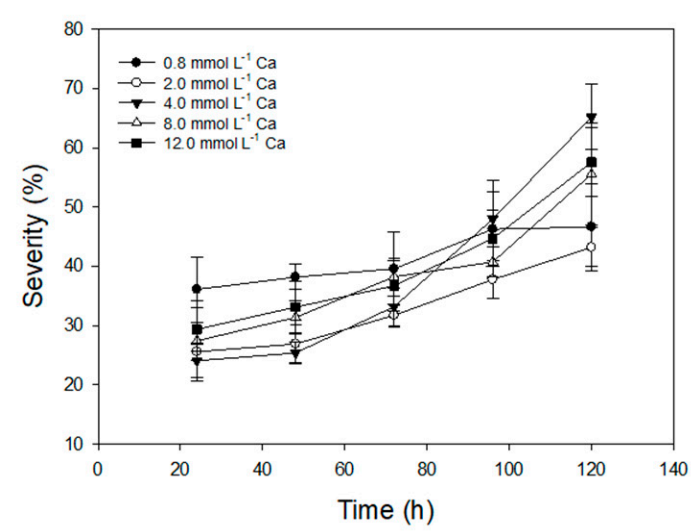

$3.0 \mathrm{~K}\left(\mathrm{mmol} \mathrm{L}^{-1}\right)$

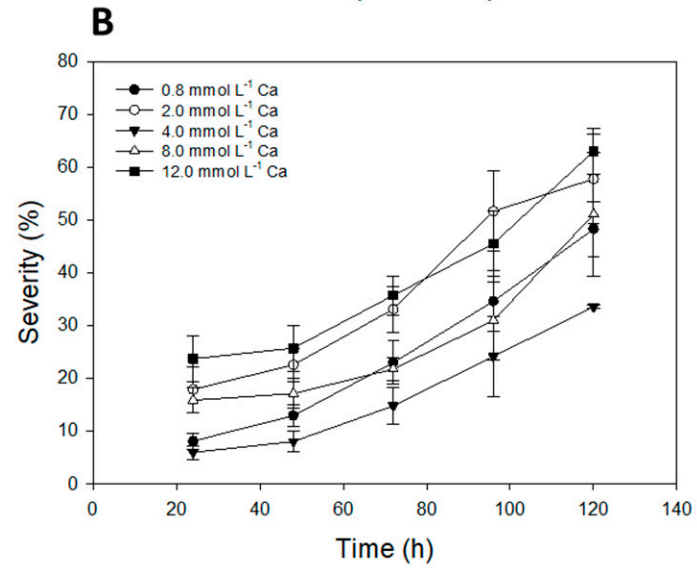

$9.0 \mathrm{~K}\left(\mathrm{mmol} \mathrm{L}^{-1}\right)$

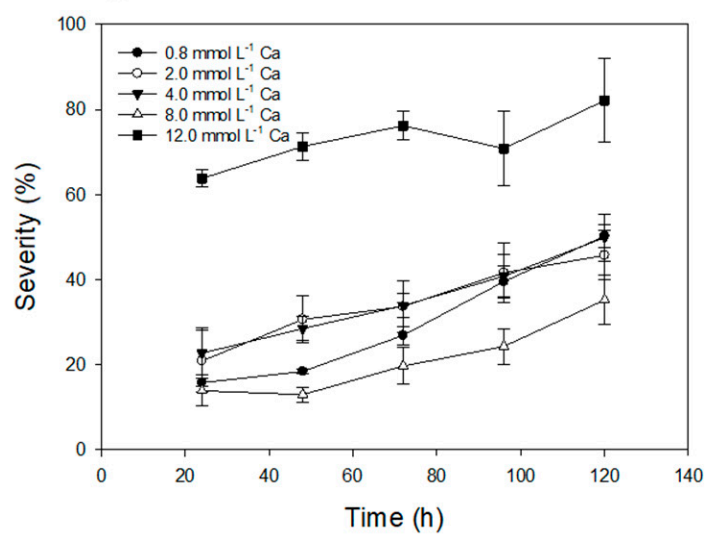

$12.0 \mathrm{~K}\left(\mathrm{mmol} \mathrm{L}^{-1}\right)$

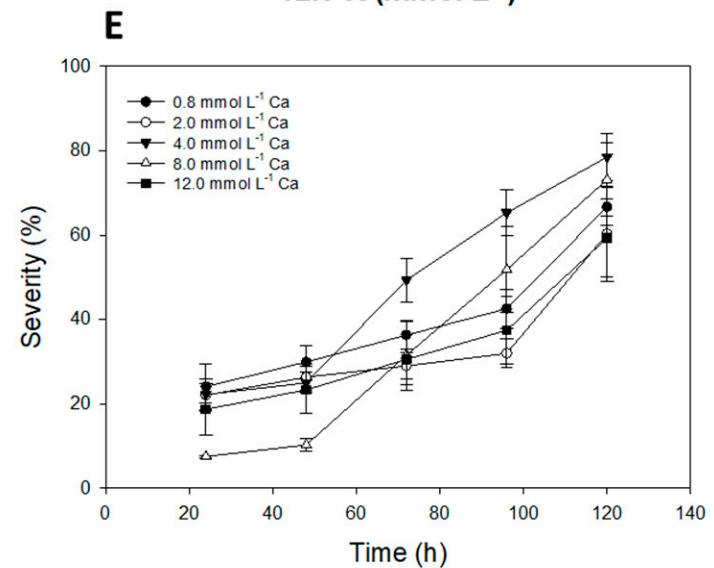

Figure 1. Severity (\%) of Calonectria leaf blight in eucalyptus over time in the presence of different doses of $\mathrm{Ca}\left(\mathrm{mmol} \mathrm{L}^{-1}\right)$ combined with (A) $1.2 \mathrm{mmol} \mathrm{L}^{-1}$, (B) $3.0 \mathrm{mmol} \mathrm{L}^{-1}$, (C) $6.0 \mathrm{mmol} \mathrm{L}^{-1}$, (D) $9.0 \mathrm{mmol} \mathrm{L}^{-1}$ and (E) $12.0 \mathrm{mmol} \mathrm{L}^{-1} \mathrm{~K}$. The bars represent the standard error. 

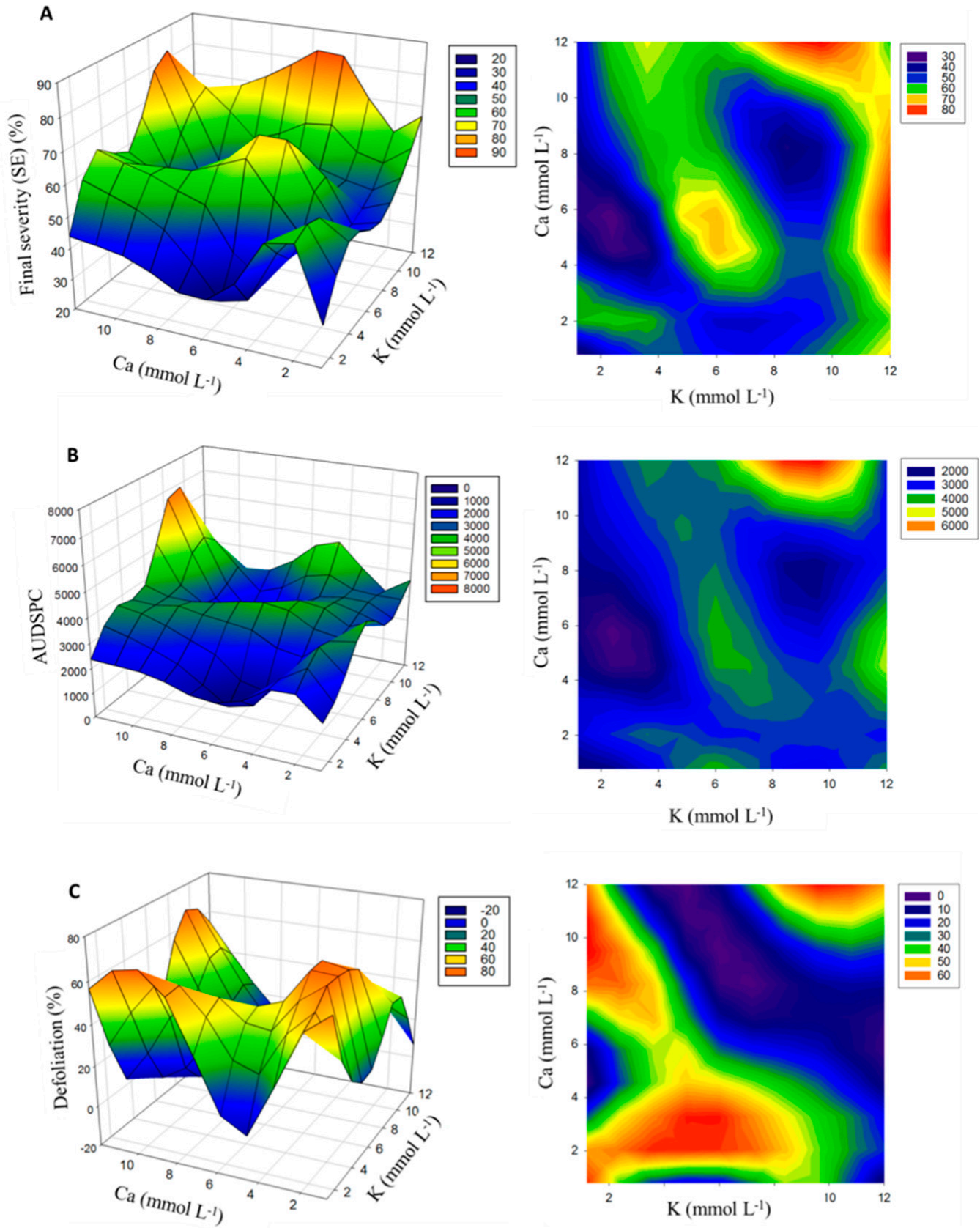

Figure 2. Influence of the supply of $\mathrm{Ca}$ and $\mathrm{K}\left(\mathrm{mmol} \mathrm{L}^{-1}\right)$ on the final severity $(\mathrm{FS})(\mathrm{A})$, area under the disease progression curve (AUDPC) (B) and defoliation (C) of eucalyptus seedlings.

\subsection{Plant Growth and Chlorophyll Content}

The interaction of the Ca and K doses affected the DRW $(p=0.0000)$ and DSW $(p=0.0000)$ as well as the DQI $(p=0.0008)$. In turn, the supply of $C a$, regardless of the supply of $K$, was significant for the $\mathrm{H}(p=0.0048)$ and chlorophyll $(p=0.0001)$ content prior to inoculation. No treatment effect on the CD $(p=0.89950)$ was observed.

The highest DRW was obtained with $6 \mathrm{mmol} \mathrm{L}^{-1} \mathrm{~K}$ combined with $8 \mathrm{mmol} \mathrm{L}^{-1} \mathrm{Ca}$, which resulted in a mean DRW of $3.69 \mathrm{~g} \mathrm{plant}^{-1}$ (Figure 3A). This treatment also led to a high DSW, with a mean value of $10.9 \mathrm{~g} \mathrm{plant}^{-1}$ (Figure 3B). The other doses did not result in significant weight gains. The supply of any dose of $\mathrm{K}$ combined with a high dose of Ca significantly increased the DQI (Figure 3C). However, the treatment consisting of $8 \mathrm{mmol} \mathrm{L}^{-1} \mathrm{~K}$ with $12 \mathrm{mmol} \mathrm{L}^{-1} \mathrm{Ca}$ exerted a notably distinct effect, with a mean of $0.23 \mathrm{~g} \mathrm{plant}^{-1}$. 
A
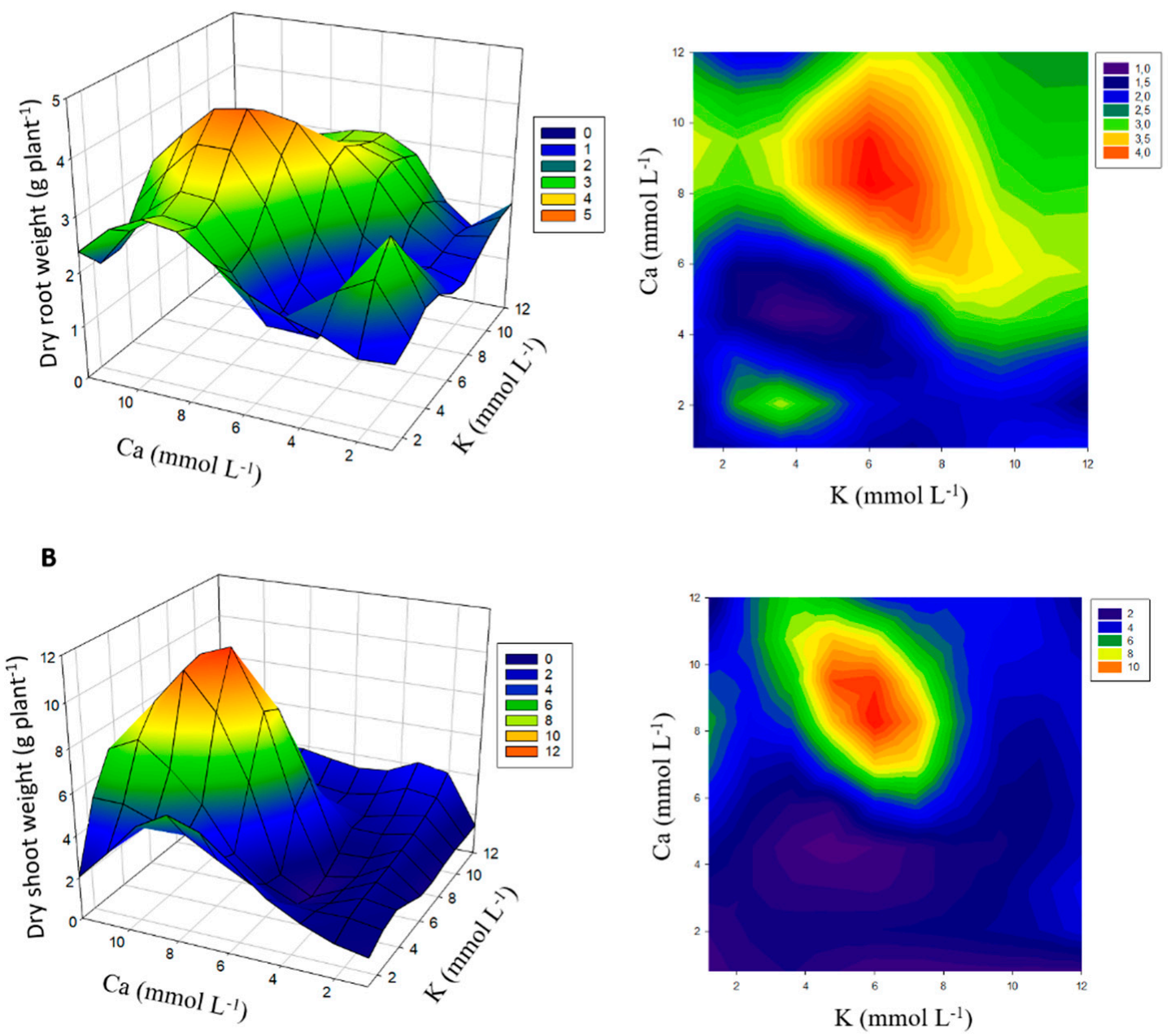

$$
\text { c }
$$
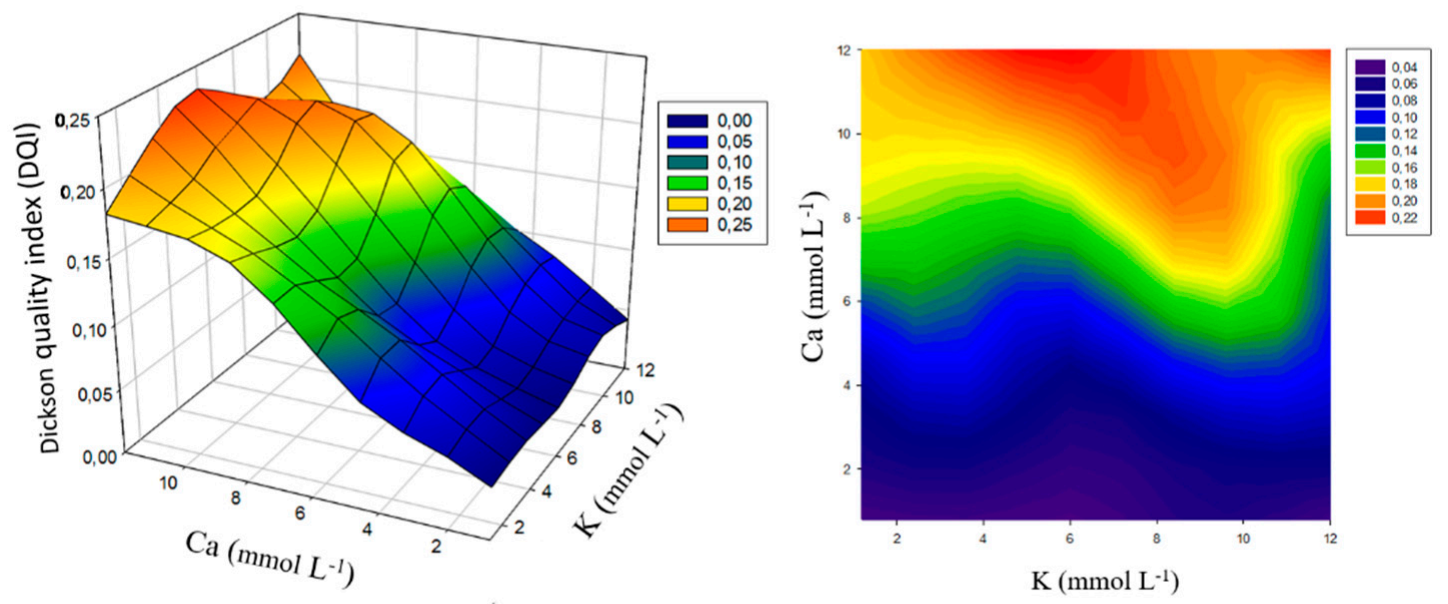

Figure 3. Influence of the supply of $\mathrm{Ca}$ and $\mathrm{K}\left(\mathrm{mmol} \mathrm{L}^{-1}\right)$ on the dry root weight $\left(\mathrm{g} \mathrm{plant}^{-1}\right)(\mathbf{A})$, dry shoot weight $\left(\mathrm{g} \mathrm{plant}^{-1}\right)(\mathbf{B})$ and Dickson quality index (DQI) (C) of eucalyptus.

An increase in the chlorophyll $a$ and $b$ contents (Figure 4) and H (Figure 5) was obtained with the supply of Ca at a dose up to $8 \mathrm{mmol} \mathrm{L}^{-1}$ and the supply of higher doses decreased the values of these variables. 
A

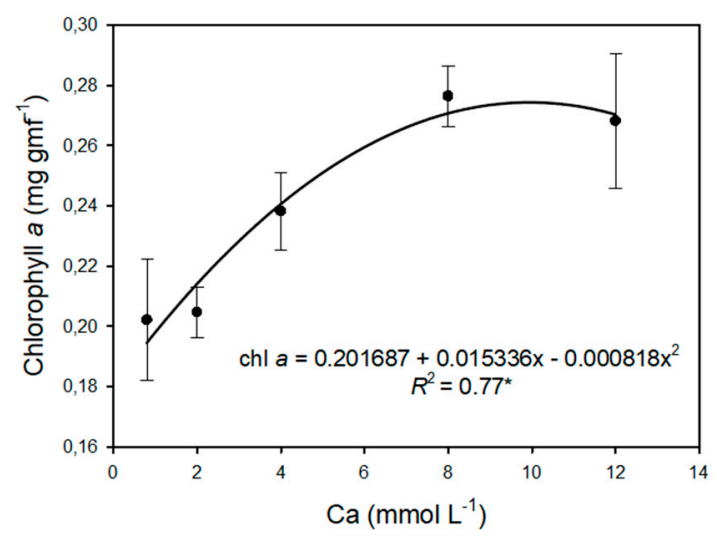

B

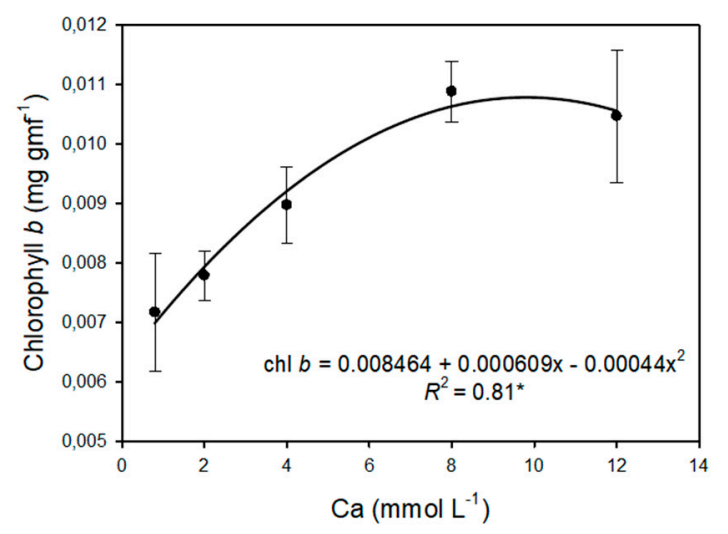

Figure 4. Contents of chlorophyll $a(\mathbf{A})$ and $b(\mathbf{B})$ of eucalyptus seedlings as a function of the calcium supply $\left(\mathrm{mmol} \mathrm{L}^{-1}\right)$. Chl: Chlorophyll. * Significant at $p \leq 0.05$. The bars represent the standard error.

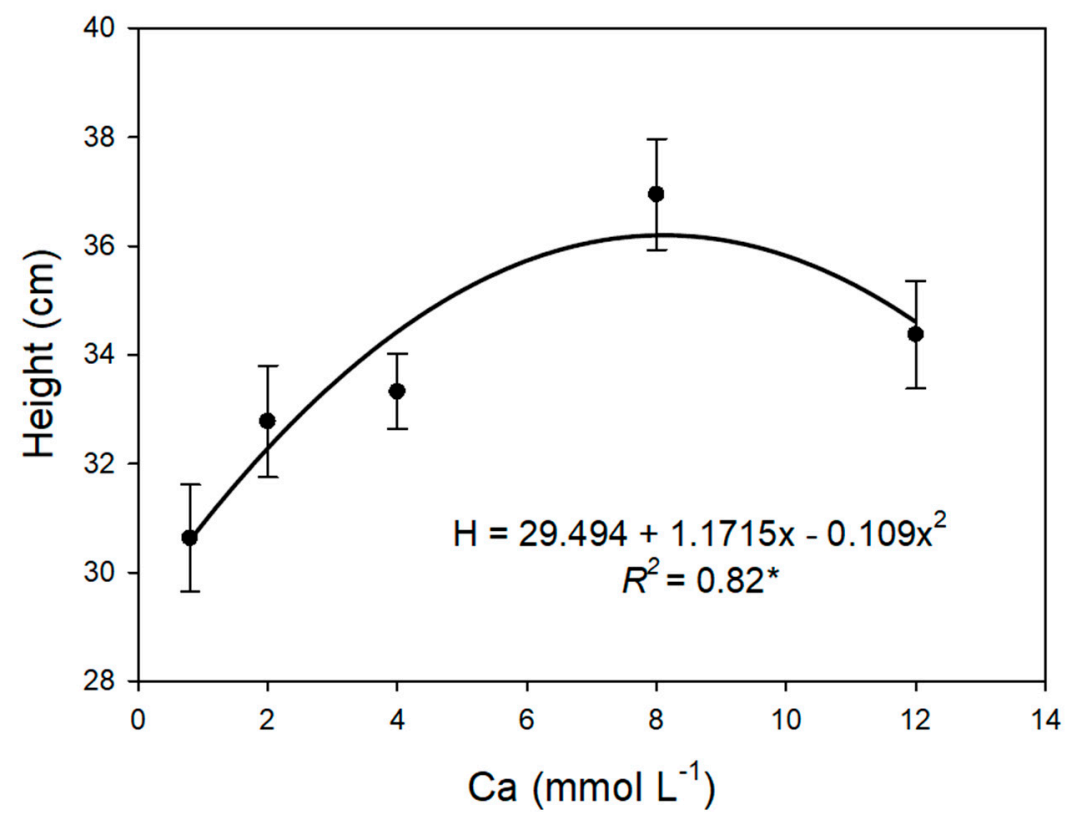

Figure 5. Effect of the calcium supply $\left(\mathrm{mmol} \mathrm{L}^{-1}\right)$ on the height of eucalyptus seedlings. * Significant at $p \leq 0.05$. The bars represent the standard error.

\subsection{Determination of Leaf Nutrient Contents}

The interaction between $\mathrm{Ca}$ and $\mathrm{K}$ exerted an effect on the contents of these same nutrients in the leaves ( $p=0.0302$ and $p=0.0040$, respectively). The leaf content of $\mathrm{K}$ relative to the initial content of $8.6 \mathrm{~g} \mathrm{~kg}^{-1}$ was increased by all the treatments. Specifically, all the treatments resulted in leaf contents of $\mathrm{K}$ above the range considered adequate for this nutrient $\left(10-12 \mathrm{~g} \mathrm{~kg}^{-1}\right)$ according to Martinez et al. [25]. However, the highest $\mathrm{K}$ contents in the leaves were obtained with the treatments consisting of $12 \mathrm{mmol} \mathrm{L}^{-1} \mathrm{~K}$ combined with 0.8 to $8 \mathrm{mmol} \mathrm{L}^{-1} \mathrm{Ca}$ (Figure $6 \mathrm{~A}$ ).

The leaf content of Ca decreased in almost all the treatments relative to the initial content of this nutrient in the leaves, $19.1 \mathrm{~g} \mathrm{~kg}^{-1}$, except in the 1.2 and $12 \mathrm{mmol} \mathrm{L}^{-1} \mathrm{~K}$ and Ca treatment, with a value of $23.7 \mathrm{~g} \mathrm{~kg}^{-1}$ (Figure 6B). The leaf Ca contents were only below the adequate range according to Martinez et al. [25] (i.e., $8-12 \mathrm{~g} \mathrm{~kg}^{-1}$ ) in the treatment with $12 \mathrm{mmol} \mathrm{L}^{-1} \mathrm{~K}_{\text {combined with doses of }}$ Ca below $8 \mathrm{mmol} \mathrm{L}^{-1}$. 

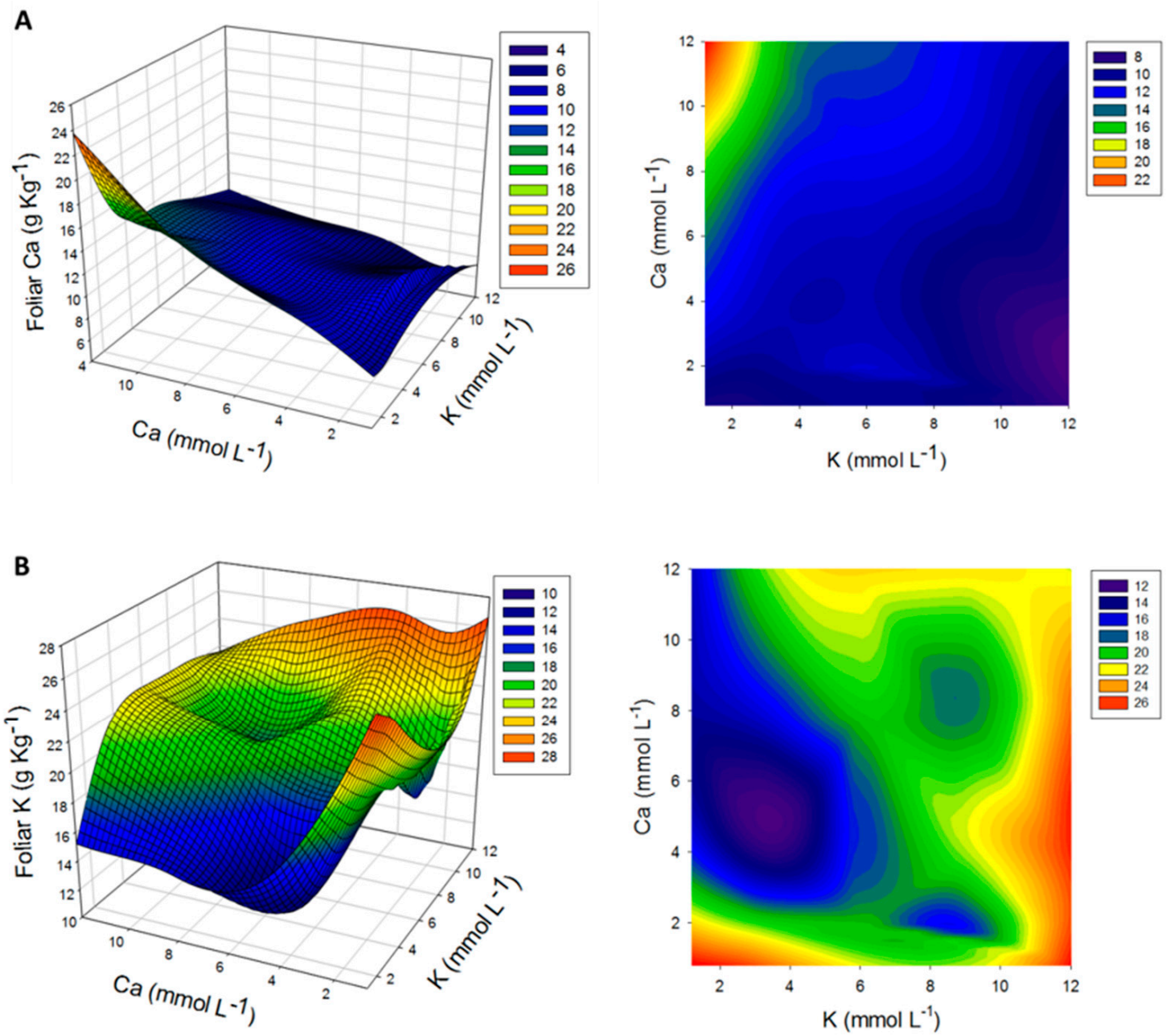

Figure 6. Leaf contents of calcium (A) and potassium (B) $\left(\mathrm{g} \mathrm{kg}^{-1}\right)$ as a function of the supply of different doses of $\mathrm{Ca}$ and $\mathrm{K}\left(\mathrm{mmol} \mathrm{L}^{-1}\right)$ in the nutrient solution.

\section{Discussion}

In this study, eucalyptus defoliation caused by C. pteridis varied according to the Ca and $\mathrm{K}$ doses. An excessive supply of both nutrients led to high disease severity combined with a high percentage of defoliation. In eucalyptus, disease-induced defoliation is the main damage resulting from a reduction in the photosynthetically active area, which can reduce the plant diameter and $\mathrm{H}$, as observed by Pulrolnik [27] in E. grandis trees.

In addition, deficiency in either $\mathrm{Ca}$ or $\mathrm{K}$ resulted in high defoliation in eucalyptus seedlings, even if the treatments resulted in a low disease severity, indicating that defoliation was not always associated with the disease. Treatment with $\mathrm{K}$ at a dose below $6 \mathrm{mmol} \mathrm{L}^{-1}$ (standard), regardless of the Ca dose, resulted in a high percentage of defoliation. Hillocks and Chinodya [28] investigated the relationship between $\mathrm{K}$ deficiency and leaf spot caused by Alternaria macrospora, which leads to defoliation in cotton and showed that K-deficient plants show early defoliation, even in the absence of the leaf pathogen. Prior to these results, premature defoliation had been attributed only to leaf spot caused by Alternaria. Thus, the results of the present study regarding the effect of $\mathrm{K}$ deficiency on defoliation are consistent with those obtained by Hillocks and Chinodya [28]. Early defoliation as a consequence of $\mathrm{K}$ deficiency is characterized by chlorophyll degradation and negative chlorophyll fluorescence, as observed by $\mathrm{Hu}$ [29], who found that K deficiency causes premature senescence of cotton leaves, decreases the leaf area and increases the rate of yellow leaves.

As observed for $\mathrm{K}$, the treatments with doses of Ca below $4 \mathrm{mmol} \mathrm{L}^{-1}$ (standard dose) combined with varying doses of $K$ resulted in significant defoliation occurred that was not associated with CLB. 
This behaviour can be explained by the influence of Ca on the K contents in the leaves. According to Tsialtas [30], high concentrations of $\mathrm{Ca}^{2+}$ in cotton leaves inhibit the exit of $\mathrm{K}^{+}$from cells under stress conditions. This conclusion was also reached in other studies [31,32], which demonstrated that an increase in the apoplastic Ca concentration reduces the stress caused by $\mathrm{K}^{+}$efflux from the mesophyll of leaves and thus ensures higher $\mathrm{K}$ retention under $\mathrm{K}$-deficiency conditions. The results of the present study suggest that $\mathrm{Ca}$ deficiency directly influences the occurrence of defoliation due to an imbalance in the $\mathrm{Ca} / \mathrm{K}$ ratio. High $\mathrm{Ca}$ concentrations allow greater $\mathrm{K}$ retention and indirectly contribute to the maintenance of cellular turgor [30].

The eucalyptus seedlings treated with $12 \mathrm{mmol} \mathrm{L}^{-1} \mathrm{~K}$ combined with any of the tested doses of Ca except $12 \mathrm{mmol} \mathrm{L}^{-1}$ presented high disease severity without defoliation. Several factors, including stomatal movement, might have contributed to the high disease severity obtained with these treatments. K exerts an important influence on stomatal opening and closing and induces rapid stomatal closure when provided at a sufficient dose; thus, pathogen infection via the stomata is directly affected by the supply of K [33]. In this study, an excessive supply of $\mathrm{K}$ might have reduced the stomatal closure responses and increased the stomatal opening movements, thereby leading to infection by C. pteridis, which penetrates exclusively via the stomata [34]. This stomatal response in the presence of high concentrations of K was detailed by Smith and Stewart [35], who subjected Striga hermonthica (Del.) Benth. plants to high concentrations of K (>200 millimolar) and observed atypical behaviour regarding the maintenance of stomatal opening and closing movements.

Although high concentrations of $\mathrm{K}$ favoured C. pteridis infection, they also contributed to the non-occurrence of defoliation, even though the seedlings showed a high necrotic leaf percentage due to the disease. This finding is again due to the notable influence of $\mathrm{K}$ on defoliation.

Compared with the FS value, the AUDPC was not representative in explaining the behaviour of CLB disease in eucalyptus and only a high disease percentage due to the interaction between $9 \mathrm{mmol} \mathrm{L}^{-1} \mathrm{~K}_{\text {and }} 12 \mathrm{mmol} \mathrm{L}^{-1} \mathrm{Ca}$ was observed based on the AUDPC, whereas other interactions, including $9 \mathrm{mmol} \mathrm{L}^{-1} \mathrm{~K}$ and $12 \mathrm{mmol} \mathrm{L}^{-1} \mathrm{Ca}$, affected the FS value. The AUDPC did not indicate the actual behaviour of CLB disease as observed at the final severity.

The $\mathrm{Ca}$ and $\mathrm{K}$ doses that yielded low disease severity and defoliation percentages also contributed positively to the evaluated morphological characteristics, leading to a high crop yield. Therefore, the overlapping of all the analysed variables would show that the regions in the graphs that favour all the desirable characteristics correspond to the interactions of $\mathrm{K}$ at doses near the standard dose $\left(6 \mathrm{mmol} \mathrm{L}^{-1}\right.$ ) with $\mathrm{Ca}$ at doses higher than $4 \mathrm{mmol} \mathrm{L}^{-1}$.

An increase in DRW was primarily obtained by the supply of Ca at a high dose and the treatments with Ca doses greater than $4 \mathrm{mmol} \mathrm{L}^{-1}$, regardless of the amount of K supplied, yielded the higher mean DRW values. The importance of Ca in root development was also demonstrated by Rodrigues [36], who found that the application of limestone to eucalyptus plants promoted an increase in the density of fine roots up to $40 \mathrm{~cm}$ in the soil. Furthermore, according Ivashuta et al. [37], the protein required for cell root cell expansion, which determines the plant's development, is dependent on $\mathrm{Ca}$ and called Ca-dependent protein kinase 1 (CDPK1). Therefore, Ca plays a key role in root development.

The treatment with $6 \mathrm{mmol} \mathrm{\textrm {L } ^ { - 1 }} \mathrm{K} \times 8 \mathrm{mmol} \mathrm{L}^{-1} \mathrm{Ca}$ resulted in good root development and great shoot development in the eucalyptus seedlings; moreover, similar doses of $\mathrm{Ca}$ and $\mathrm{K}$ resulted in greater increases in the DSW compared with the other treatment doses. Both nutrients participate in physiological processes related to plant growth and influence cambium activity and xylem development, which are important in wood formation [38]. K participates in the regulation of the osmotic potential and cell expansion and $\mathrm{Ca}$ is involved in a number of processes, such as cell division, cell wall chemistry and cell differentiation; therefore, both nutrients promote increases in the cambium width [39]. Moreover, according to Laclau et al. [40], fertilization with K significantly increases the leaf biomass of E. grandis as well as its leaf life span. 
The significant increase in the dry organ weights (i.e., DRW and DSW) obtained with $6 \mathrm{mmol} \mathrm{L}^{-1} \mathrm{~K}$ and $8 \mathrm{mmol} \mathrm{L}^{-1} \mathrm{Ca}$ indicated that the amount of Ca supplied to eucalyptus plants in the standard solution was insufficient to achieve the desired morphological characteristics. The DQI results validate this conclusion because the treatments that yielded the highest indices included $\mathrm{Ca}$ at doses above the standard dose $\left(4 \mathrm{mmol} \mathrm{L}^{-1}\right)$ and the findings were independent of the dose of $\mathrm{K}$. In addition, the highest mean chlorophyll $a$ and $b$ contents and $\mathrm{H}$ values were observed in the seedlings supplied $8 \mathrm{mmol} \mathrm{L}^{-1}$ Ca.

According to the results of the leaf analysis, the treatments with a high K supply resulted in lower leaf contents of Ca compared with those obtained with the other treatments, indicating that these nutrients compete for the same absorption site in the plant [40]. In general, reducing the supply of one of the nutrients increased the leaf content of the other nutrient. Only the treatments with low doses of $\mathrm{K}$ yielded a leaf content of $\mathrm{Ca}$ above the range considered adequate by Martinez et al. [25]. Thus, an excess supply of $\mathrm{K}$ reduces the uptake of $\mathrm{Ca}$ and leads to the accumulation of $\mathrm{K}$ in the leaves. In addition, the high leaf content of $\mathrm{K}$ observed with the treatments consisting of $12 \mathrm{mmol} \mathrm{L}^{-1} \mathrm{~K}$ confirmed that imbalances in this nutrient cause issues in stomatal movement and thereby lead to high disease severity.

\section{Conclusions}

In practice, the use of mineral fertilization regimes in the production of eucalyptus seedlings that increase the supply of Ca while maintaining the dose of $\mathrm{K}$ at a level close to the standard dose used in this study can ensure higher crop growth and reduce losses related to defoliation due to increases in disease and defoliation susceptibility attributed to unbalanced fertilization.

Author Contributions: Conceptualization, T.P.F.S. and M.A.F.; Methodology, T.P.F.S., E.A.P., and A.A.A.P.; Software, T.P.F.S.; Validation, T.P.F.S., E.A.P., A.A.A.P., R.G.M. and M.A.F.; Formal Analysis, T.P.F.S.; Investigation, T.P.F.S.; Resources, E.A.P. and M.A.F.; Data Curation, T.P.F.S., E.A.P., A.A.A.P., R.G.M. and M.A.F.; Writing-Original Draft Preparation, T.P.F.S.; Writing—Review \& Editing, T.P.F.S., E.A.P., A.A.A.P., R.G.M. and M.A.F.; Visualization, T.P.F.S., E.A.P., A.A.A.P., R.G.M. and M.A.F.; Supervision, M.A.F.; Project Administration, M.A.F.; Funding Acquisition, M.A.F.

Funding: This research was funded by Coordenação de Aperfeiçoamento de Pessoal de Nível Superior grant number (scholarship) and The APC was funded by Maria A. Ferreira, Fundação de Desenvolvimento Científico e Cultural.

Acknowledgments: We would like to acknowledge the funding and scholarships from the Coordenação de Aperfeiçoamento de Pessoal de Nível Superior Coordination for the Improvement of Higher Education Personnel (CAPES).

Conflicts of Interest: The authors declare no conflict of interest.

\section{References}

1. Ibá—Indústria Brasileira de Árvores. Available online: http://iba.org/images/shared/Biblioteca/IBA_ RelatorioAnual2017.pdf (accessed on 3 October 2017).

2. Hinchee, M.; Rottmann, W.; Mullinax, L.; Zhang, C.; Chang, S.; Cunningham, M.; Pearson, L.; Nehra, N. Short-rotation woody crops for bioenergy and biofuels applications. In Biofuels; Springer: New York, NY, USA, 2009; pp. 139-156.

3. Shepherd, M.; Bartle, J.; Lee, D.J.; Brawner, J.; Bush, D.; Turnbull, P. Eucalypts as a biofuel feedstock. Biogeosciences 2011, 2, 639-657. [CrossRef]

4. Alfenas, A.C.; Zauza, E.A.V.; Mafia, R.G.; Assis, T.F. Clonagem e Doenças do Eucalipto, 2nd ed.; Editora, U.F.V., Viçosa, M.G., Eds.; Editora UFV: Viçosa, Brazil, 2009; p. 500.

5. Rodas, C.A.; Lombard, L.; Gryzenhout, M.; Slippers, B.; Wingfield, M.J. Cylindrocladium blight of. Eucalyptus grandis in Colombia. Australas. Plant Pathol. 2005, 34, 143-149. [CrossRef]

6. Alfenas, A.C.; Ferreira, F.A. A mancha de folha do eucalipto no Brasil causada por três espécies de Cylindrocladium-Uma revisão da descrição da doença. Revista Árvore 1979, 3, 47-56. 
7. Ferreira, F.A.; Alfenas, A.C.; Moreira, A.M.; Demuner, N.L. Mancha-depteridis doença foliar de eucalipto em areas tropicais brasileiras. Fitopatol. Bras. 1995, 20, 107-110.

8. Alfenas, A.C.; Zauza, E.A.V.; Mafia, R.G.; Assis, T.F. Clonagem e Doenças do Eucalipto; Editora UFV: Viçosa, Brazil, 2004; p. 442.

9. Ferreira, E.M.; Alfenas, A.C.; Mafia, L.A.; Mafia, R.G. Eficiência de fungicidas sistêmicos para o controle de Cylindrocladium candelabrum em eucalipto. Fitopatol. Bras. 2006, 31, 468-475. [CrossRef]

10. Datnoff, L.E.; Rodrigues, F.A.; Seebold, K.W. Silicon and Plant Nutrition. In Mineral Nutrition and Plant Disease; Datnoff, L.E., Elmer, W.H., Huber, D.M., Eds.; APS Press: Saint Paul, MN, USA, 2007; pp. $233-246$.

11. Wang, M.; Zheng, Q.; Shen, Q.; Guo, S. The critical role of potassium in plant stress response. Int. J. Mol. Sci. 2013, 14, 7370-7390. [CrossRef] [PubMed]

12. Jakobsen, T.J. Interaction between Plant Nutrients: 1. Theory and Analytical Procedures. Acta Agric. Scand. Section B-Soil Plant Sci. 1992, 42, 208-212. [CrossRef]

13. Jakobsen, T.J. Interaction between Plant Nutrients: III. Antagonism between Potassium, Magnesium and Calcium. Acta Agric. Scand. Section B-Soil Plant Sci. 1993, 43, 1-5. [CrossRef]

14. Zhang, L.; Du, L.; Poovaiah, B.W. Calcium signaling and biotic defense responses in plants. Plant Signal. Behav. 2014, 9, e973818. [CrossRef]

15. Armengaud, P.; Breitling, R.; Amtmann, A. The potassium-dependent transcriptome of Arabidopsis reveals a prominent role of jasmonic acid in nutrient signaling. Plant Physiol. 2004, 136, 2556-2576. [CrossRef]

16. Ma, W.; Qi, Z.; Smigel, A.; Walker, R.K.; Verma, R.; Berkowitz, G.A. Ca ${ }^{2+}$, cAMP, and transduction of nonself perception during plant immune responses. Proc. Nat. Acad. Sci. USA 2009, 106, 20995-21000. [CrossRef] [PubMed]

17. Rahman, M.; Punja, Z.K. Calcium and plant disease. In Mineral Nutrition and Plant Disease; Datnoff, L.E., Elmer, W.H., Huber, D.M., Eds.; American Phytopathological Society Press: Saint Paul, MN, USA, 2007; Volume 1, pp. 79-93.

18. Clark, R.B. Characterization of phosphates in intact maize roots. J. Agric. Food Chem. 1975, 23, 458-460. [CrossRef] [PubMed]

19. Alfenas, R.F. Produção de Inóculo de Cylindrocladium pteridis em Condições Controladas. Master's Thesis, Federal University of Viçosa, Viçosa, Brazil, October 2009.

20. Vale, F.X.R.; Fernandes, F.E.I.F.; Liberato, J.R. QUANT—A software for plant disease severity assessment. In Proceedings of the Anais International Congress of Plant Pathology, Christchurch, New Zealand, 2-7 February 2003.

21. Dickson, A.; Leaf, A.L.; Hosner, J.F. Quality appraisal of white spruce and white pine seedling stock in nurseries. For. Chron. 1960, 36, 10-13. [CrossRef]

22. Shaner, G.; Finney, R.E. The effect of nitrogen fertilization on the expression of slow-mildew resistance in Knox wheat. Phytopathology 1977, 67, 1051-1056. [CrossRef]

23. Matsumoto, S.N.; Carvalho, F.M.; Viana, A.E.S.; Malta, M.R.; Castro, L.G. Initial growth of coffee plants (Coffea Arabica L.) submitted to different phosphate doses in nutritive solution. Coffee Sci. 2008, 31, 58-67.

24. Malavolta, E.; Vitti, G.C.; Oliveira, S.A. Avaliação do Estado Nutricional das Plantas: Princípios e Aplicações, 2nd ed.; POTAFOS: Piracicaba, Brazil, 1997; p. 319.

25. Martinez, H.E.P.; Carvalho, J.G.; Souza, R.B. Diagnose foliar. In Recomendações para Uso de Corretivos e Fertilizantes em Minas Gerais: 5 Aproximação; Ribeiro, A.C., Guimarães, P.T.G., Alvarez, V.V.H., Eds.; CFSEMG: Viçosa, Brazil, 1999; pp. 143-168.

26. Shapiro, S.S.; Wilk, M.B. An analysis of variance test for normality (complete samples). Biometrika 1965, 52, 591-611. [CrossRef]

27. Pulrolnik, K.; Reis, G.G.; Reis, M.G.F.; Monte, M.A.; Fontan, I.C.I. Crescimento de plantas de clone de Eucalyptus grandis [hillexmaiden] submetidas a diferentes tratamentos de desrama artificial, na região de cerrado. Revista Árvore 2005, 29, 495-505. [CrossRef]

28. Hillocks, R.J.; Chindoya, R. The relationship between Alternaria leaf spot and potassium deficiency causing premature defoliation of cotton. Plant Pathol. 1989, 38, 502-508. [CrossRef]

29. Hu, W.; Lv, X.; Yang, J.; Chen, B.; Zhao, W.; Meng, Y.; Oosterhuis, D.M. Effects of potassium deficiency on antioxidant metabolism related to leaf senescence in cotton (Gossypium hirsutum L.). Field Crop. Res. 2016, 191, 139-149. [CrossRef] 
30. Tsialtas, J.T.; Shabala, S.; Matsi, T. A prominent role for leaf calcium as a yield and quality determinan in upland cotton (Gossypium hirsutum L.) varieties grown under irrigated Mediterranean conditions. J. Agron. Crop Sci. 2016, 202, 161-173. [CrossRef]

31. Shabala, S.; Pottosin, I. Regulation of potassium transport in plants under hostile conditions: Implications for abiotic and biotic stress tolerance. Physiol. Plant. 2014, 151, 257-279. [CrossRef]

32. Reddy, K.R.; Hodges, H.F.; Varco, J. Potassium nutrition of cotton. Miss. Agric. For. Exp. Stn. 2000, 1094, 1-10.

33. Pervez, H.; Ashraf, M.; Makhdum, M.I.; Mahmood, T. Potassium nutrition of cotton (Gossypium hirsutum L.) in relation to cotton leaf curl virus disease in aridisols. Pak. J. Bot. 2007, 39, 529-539.

34. Graça, R.N.; Alfenas, A.C.; Maffia, L.A.; Titon, M.; Alfenas, R.F.; Lau, D.; Rocabado, J.M.A. Factors influencing infection of eucalypts by Cylindrocladium pteridis. Plant Pathol. 2009, 58, 971-981. [CrossRef]

35. Smith, S.; Stewart, G.R. Effects of potassium levels on the stomatal behavior of the hemi-parasite Striga hermonthica. Plant Physiol. 1990, 94, 1472-1476. [CrossRef] [PubMed]

36. Rodrigues, F.A.V. Crescimento de Eucalipto em Idade Jovem e Movimentação de Cálcio e Magnésio no Solo em Resposta à Aplicação de Calcário e Gesso Agrícola. Ph.D. Thesis, Universidade Federal de Viçosa, Viçosa, Brazil, April 2013.

37. Ivashuta, S.; Liu, J.; Lohar, D.P.; Haridas, S.; Bucciarelli, B.; VandenBosch, K.A.; Vance, C.P.; Harrison, M.J.; Gantt, J.S. RNA interference identifies a calcium-dependent protein kinase involved in Medicago truncatula root development. Plant Cell 2005, 17, 2911-2921. [CrossRef] [PubMed]

38. Fromm, J. Wood formation of trees in relation to potassium and calcium nutrition. Tree Physiol. 2010, 30, 1140-1147. [CrossRef] [PubMed]

39. Fageria, V.D. Nutrient interactions in crop plants. J. Plant Nutr. 2001, 24, 1269-1290. [CrossRef]

40. Laclau, J.P.; Almeida, J.C.R.; Gonçalves, J.L.M.; Saint-Andre, L.; Ventura, M.; Ranger, J.; Moreira, R.M.; Nouvellon, Y. Influence of nitrogen and potassium fertilization on leaf life span and allocation of above-ground growth in Eucalyptus plantations. Tree Physiol. 2009, 29, 111-124. [CrossRef]

(C) 2018 by the authors. Licensee MDPI, Basel, Switzerland. This article is an open access article distributed under the terms and conditions of the Creative Commons Attribution (CC BY) license (http:/ / creativecommons.org/licenses/by/4.0/). 